Available online at GSC Online Press Directory

GSC Biological and Pharmaceutical Sciences

e-ISSN: 2581-3250, CODEN (USA): GBPSC2

Journal homepage: https://www.gsconlinepress.com/journals/gscbps

(RESEARCH ARTICLE)

\title{
Evaluation of the toxic effects of Albizia mahalao Capuron extracts, a Fabaceae from Madagascar, on different organisms
}

\author{
Razanatseheno Andriantsihoarana Jonathan, Randriamampianina Lovarintsoa Judicaël, Randrianarivo \\ Hanitra Ranjàna, Rakoto Danielle Aurore Doll and Jeannoda Victor Louis * \\ Laboratory of Applied Biochemistry in Medical Sciences, Department of Fundamental and Applied Biochemistry, Faculty \\ of Sciences, University of Antananarivo, BP 906, Antananarivo 101, Madagascar.
}

Publication history: Received on 19 May 2020; revised on 24 May 2020; accepted on 27 May 2020

Article DOI: https://doi.org/10.30574/gscbps.2020.11.2.0144

\begin{abstract}
This work was designed to study the toxic effects of Albizia mahalao extracts on various organisms and explore their possible uses to fight against noxious organisms. Methanolic extracts of leaves (LME), stem (SME) and root (RME) barks, alkaloids (Alk) and saponosides (Sap) from leaves were tested. All extracts were toxic to mice with $\mathrm{LD}_{50}$ values by intraperitoneal route ranging from 69.18 (RME) to $135.52 \mathrm{mg} / \mathrm{kg}$ body weight (Alk). By oral route, at doses 5 and 10 times higher than intraperitoneal $\mathrm{LD}_{100}$ those extracts were not toxic. LME, SME and RME were toxic to carp alvins, frog tadpoles but not to chicks and mosquito Culex quinquefasciatus larvae. LC 50 on carp alvins varied from 63.78 (RME) to $86.89 \mu \mathrm{g} / \mathrm{mL}$ (SME) and $\mathrm{LC}_{50}$ on frog tadpoles from 68.43 (RME) to $153.4 \mu \mathrm{g} / \mathrm{mL}$ (SME). All the methanolic extracts inhibited the germination of $53.8 \%$ of the seed plants tested with inhibition percentages ranging from 20 to $100 \%$. In previous study, the same Albizia mahalao extracts were found to be efficient against many pathogenic bacteria at low doses. The extracts non-toxicity by oral route allowed envisaging their use to treat some diseases associated with these bacteria.
\end{abstract}

Keywords: Albizia mahalao; Fabaceae; Toxicity; Alkaloids; Saponosides; Warm and Cold-blooded Animals; Seed Germination.

\section{Introduction}

Albizia is a very cosmopolitan botanical genus including about 150 species extensively distributed in tropical and subtropical regions. In Madagascar, 30 Albizia species are present 24 of which are endemic, 3 also occur elsewhere and 3 are introduced [1]. A research program on toxic plants endemic to Madagascar including Albizia species has been conducted in our laboratory. Several Malagasy Albizia spp. such as A. divaricata, A. greveana, A. masikororum, A. tulearensis, $A$. viridis and $A$. bernieri were already proved to be toxic to various organisms $[2,3,4]$.

The antimicrobial activities we reported in a previous paper [5], showed the efficiency of the methanolic extracts and alkaloid fraction from A. mahalao against pathological bacteria strains for human like Clostridium perfringens, Salmonella enterica and Shigella flexneri. These results led us to pursue our investigations on A. mahalao in order to identify other biological properties that could serve useful purposes such as the control of noxious organisms.

The present work focused on the study of the toxicological effects of methanol extracts and total alkaloids and saponosides from leaves, stem and root bark of Albizia mahalao on various cold and warm-blooded animals and plant seed germination.

\footnotetext{
* Corresponding author: Jeannoda Victor Louis
} 


\section{Material and methods}

\subsection{Plant material}

A. mahalao Capuron is a tree growing up to $5 \mathrm{~m}$ high (Figure 1 ).

Fresh leaves, root and stem barks of $A$. mahalao were collected from Tsimanampetsotsa (South west of Madagascar) with the following geographical coordinates: $24^{\circ} 02^{\prime} 19.13^{\prime \prime}$ latitude; $43^{\circ} 45^{\prime} 08.28^{\prime \prime}$ longitude; $7 \mathrm{~m}$ altitude.

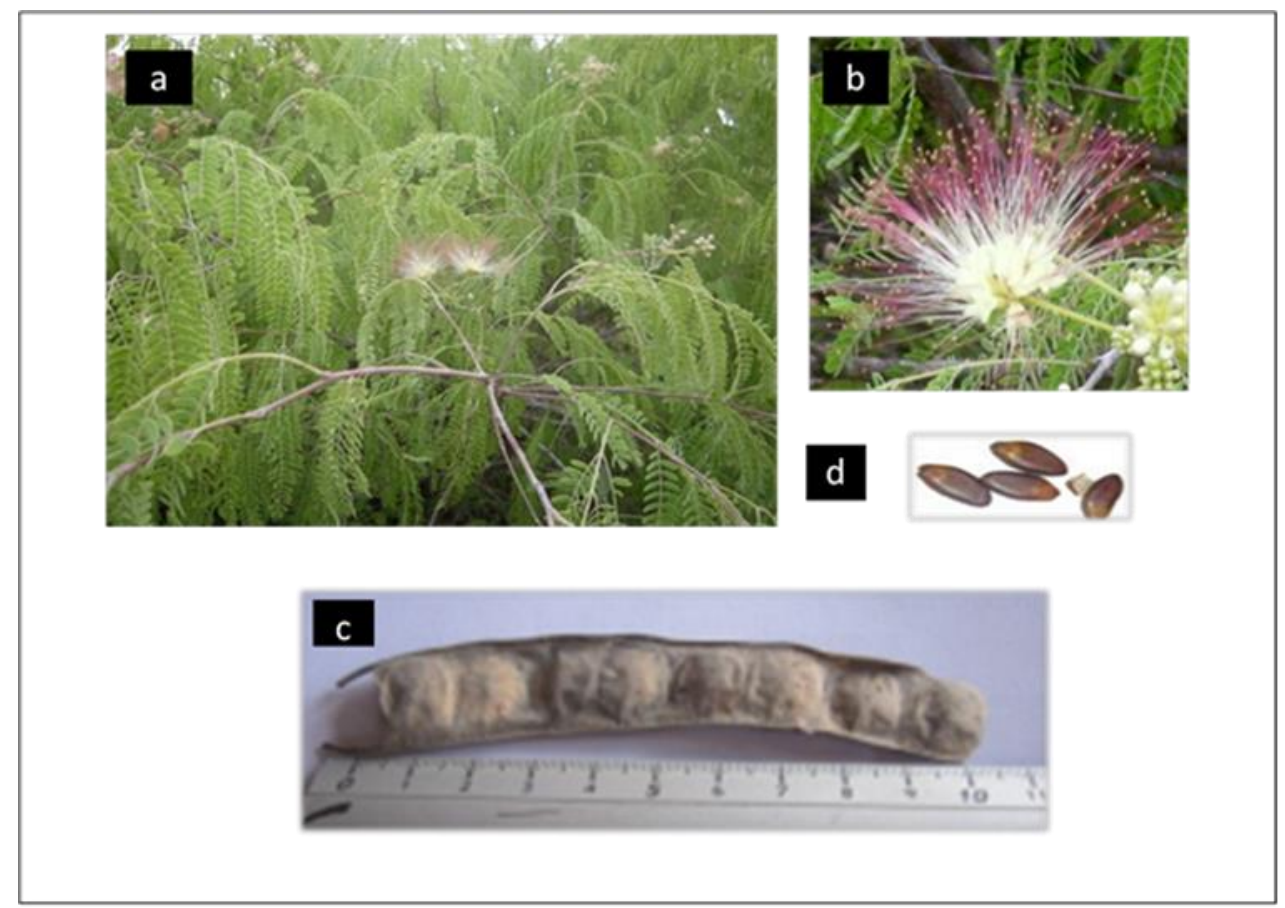

Figure 1 Albizia mahalao (a) the whole plant; (b) flower; (c) fruit; (d) seeds (Source: The authors)

\subsection{Plant seeds}

The seeds of 11 plants belonging to 8 botanical families were used for germination tests (Table 1). They were purchased from an approved seed supplier.

Table 1 List of plants whose seeds were used for germination assays

\begin{tabular}{ll}
\hline Plant family & Species \\
\hline Apiaceae & Daucus carotta \\
Asteraceae & Lactuca sativa \\
& Brassica chinensis \\
& Brassica oleraceae \\
Brassicaceae & Brassica sp \\
& Raphanus sativus \\
Cucurbitaceae & Cucumis sp \\
Fabaceae & Phaseolus vulgaris \\
& Pisum sativum \\
Papilionaceae & Glycine max \\
Solanaceae & Lycopersicum esculentum \\
Poaceae & Oryza sativa \\
& Zea mays \\
\hline
\end{tabular}




\subsection{Animals}

\subsection{Warm-blooded animals}

OF-1 strain Albino mice (Mus musculus), weighing $25 \pm 2 \mathrm{~g}$, were provided by the Institut Pasteur de Madagascar (IPM) breeding farm.

Day-old chicks (Gallus gallus domesticus) were provided by an approved farm (AVITECH).

\subsubsection{Cold-blooded animals}

Mosquito larvae (Culex quinquefasciatus) were collected from ponds or puddles in the Antananarivo University site.

Carp alvins (Cyprinus carpio), Royal strain, 2-3 cm size, were furnished by an approved fish farmer in Ambohimangakely, Antananarivo, Madagascar.

Apode frog tadpoles (Ptychadena mascareniensis) were harvested from ponds in the vicinity of Antananarivo University site.

Fishes and tadpoles were allowed to acclimatize to the aquarium conditions for one day after their arrival in laboratory.

\subsection{Extracts preparation}

The methanolic and alkaloids extracts used in this work were prepared by the method described in our previous paper [5]. The saponosides extract was obtained according to Randriamampianina et al. [3]. All these extracts are presented in table 2.

Table 2 List of $A$. mahalao extracts used

\begin{tabular}{lll}
\hline Extract name & Designation & Plant part \\
\hline Leaf methanolic extract & LME & Leaf \\
Stem bark methanolic extract & SME & Stem bark \\
Root bark methanolic extract & RME & Root bark \\
Total saponosides & Sap & Leaf \\
Total alkaloids & Alk & Leaf \\
\hline
\end{tabular}

\subsection{Toxicity determination}

\subsubsection{Toxicity test on warm-blooded animals}

\subsubsection{Acute toxicity test}

Different administration routes were used for assessing acute toxicity on mice and chicks. For intraperitoneal (ip) and subcutaneous (sc) routes, $0.3 \mathrm{~mL}$ of extracts was injected per $25 \pm 2 \mathrm{~g}$ of body weight. Concerning the oral or per os (po) route, $0.25 \mathrm{~mL}$ of extracts per $25 \pm 2 \mathrm{~g}$ of body weight was administered by means of an intubation cannula with a curved distal.

\subsubsection{LD $\mathrm{LD}_{50}(24 \mathrm{~h})$ assessment on mice}

Seven different doses of methanolic extracts, total alkaloids and saponosides of $A$. mahalao were injected by ip route on seven groups of five male mice. Another group receiving physiological serum served as control.

\subsubsection{Toxicity test on cold-blooded animals}

\subsubsection{Acute toxicity test on fishes and frog tadpoles}

Groups of five animals were placed in $500 \mathrm{~mL}$ crystallizers containing $250 \mathrm{~mL}$ of spring water. Different concentrations of methanolic extracts of $A$. mahalao were added. One group without extract served as a control. 


\subsubsection{LC $\mathrm{L}_{50}(24 \mathrm{~h})$ assessment}

The $\mathrm{LC}_{50}(24 \mathrm{~h})$ of each extract was determined on fishes and frog tadpoles using different concentrations. The tests were carried out in triplicate. Results were treated using the method of statistical analysis ANOVA with Graphpad Prism 7 software. Statistical values were expressed in $95 \%$ confidence interval.

\subsubsection{Acute toxicity test on mosquito larvae}

Culex quinquefasciatus larvae in the third stage of development (size $=5 \mathrm{~mm}$ ) were distributed in batch of 25 and deposited in $200 \mathrm{~mL}$ of tested extract at $2 \mathrm{mg} / \mathrm{mL}$. After $24 \mathrm{~h}$, larval mortality resulted in complete immobility (knockdown) of the larvae or their inability to surface or dive when their environment was agitated.

\subsubsection{Seed germination assays}

Seeds were sterilized by soaking in sodium hypochlorite solution (5\%). After $1 \mathrm{~min}$., they were immediately washed with distilled water. One lot of 10 seeds of each plant test was separately soaked in each of methanolic extracts at 1 $\mathrm{mg} / \mathrm{mL}$ during $48 \mathrm{~h}$ in the dark and another one in distilled water served as control. Seeds were then transferred on to Petri dish lined with cotton soaked with extracts (tests) or with distilled water (control). Each treatment was carried out in three replicates. During 15 days, substrate was moistened every two days with extract (test) or water (control) and germinated seeds were counted. Results were expressed as germination percentage.

\section{Results}

\subsection{Effects of extracts on warm-blooded animals}

\subsubsection{Effects on mice}

At the doses used $(252,120,168,228$ and $312 \mathrm{mg} / \mathrm{kg}$ body weight respectively for LME, RME, SME, Alk and Sap, all the extracts were toxic to mice by ip but not by po and sc routes. The developed symptoms were generally similar. The main symptoms visible before death were abdominal contortion, ataxia, piloerection, dyspnea, ear hyperemia, profuse salivation and clonic convulsions.

By po route, at doses 5 and 10 times higher than DL100 by ip route (Table 3), LME, RME and SME, caused only decreases in motor activity during 1 to $2 \mathrm{~h}$. Complete remission was observed after $3 \mathrm{~h}$. No mortality was recorded $24 \mathrm{~h}$ after forcefeeding.

The values of LD50 $24 \mathrm{~h}$ by ip route of the extracts ranged from 69.18 (RME) to $135.52 \mathrm{mg} / \mathrm{mL}$ (Alk).

Table 3 Lethal doses (LD) of methanol extracts, Alk and Sap on mice

\begin{tabular}{llll}
\hline Extracts & \multicolumn{3}{c}{ Lethal Dose (LD) (mg/kg body weight) } \\
\hline & $\mathrm{LD}_{0}$ & $\mathrm{LD}_{50}$ & $\mathrm{LD}_{100}$ \\
$\mathrm{LME}$ & 69.32 & 118.57 & 252 \\
$\mathrm{RME}$ & 46.78 & 69.18 & 120 \\
$\mathrm{SME}$ & 80.26 & 123.03 & 168 \\
$\mathrm{Alk}$ & 93.58 & 135.52 & 228 \\
Sap & 70.94 & 131.22 & 312 \\
\hline \multicolumn{4}{c}{ LD $_{0}:$ Lethal Dose $0 \% ;$ LD $_{50}:$ Lethal Dose $50 \% ; \mathrm{LD}_{100}:$ Lethal Dose $100 \%$}
\end{tabular}

\subsubsection{Effects on chicks}

At $2520 \mathrm{mg} / \mathrm{kg}$ (LME), $1200 \mathrm{mg} / \mathrm{kg}$ (RME) and $1680 \mathrm{mg} / \mathrm{kg}$ (SME) that were doses ten times higher than ip lethal doses in mice, all extracts were not toxic to chicks. 


\subsection{Effects of methanolic extracts on cold-blooded animals}

\subsubsection{Effects on carp alvins}

Seven concentrations ranging from $41.94 \mu \mathrm{g} / \mathrm{mL}$ to $175 \mu \mathrm{g} / \mathrm{mL}$ in geometric progression having ratios of 1.25 (LME), 1.12 (RME) and 1.23 (SME), were tested on 7 lots of 5 alvins. The 3 methanolic extracts were toxic on carp alvins. A dose-dependent ( $p$-value<0.05) increase in the effects was registered (Figure 2).
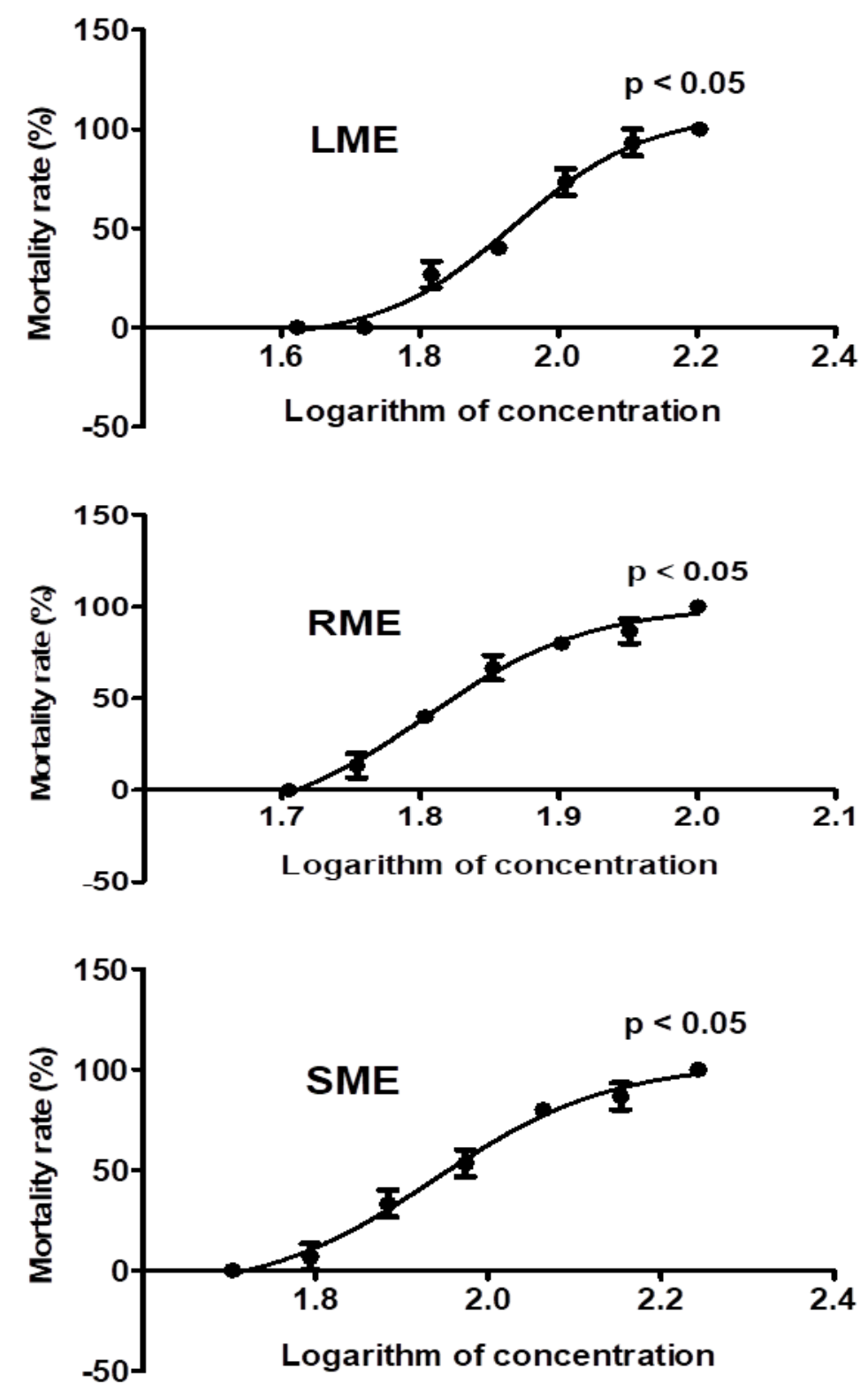

Figure 2 Concentration-effect curves of RME, SME and SME on carp alvins

The lethal concentrations ( $\mathrm{LC}_{0}, \mathrm{LC}_{50}$ and $\mathrm{LC}_{100}$ ) were determined (Table 4). LC varied from $41.94 \mu \mathrm{g} / \mathrm{mL}$ (LME) to 50.66 ( $\mu \mathrm{g} / \mathrm{mL}$ RME), $\mathrm{LC}_{50}$ from $63.78 \mu \mathrm{g} / \mathrm{mL}$ (RME) to $86.89 \mu \mathrm{g} / \mathrm{mL}$ (SME) and $\mathrm{LC}_{100}$ from $100 \mu \mathrm{g} / \mathrm{mL}$ (RME) to $175 \mu \mathrm{g} / \mathrm{mL}$ (SME).

Besides, statistical analyses showed that there was no significant difference between the effects of the three organs ( $p$ value $<0.05$ ) 
Table 4 Lethal concentrations (LC) of methanolic extracts on carp alvins

\begin{tabular}{llll}
\hline Extracts & $\mathbf{L C 0} \boldsymbol{\mu g} / \mathbf{m L})$ & $\mathbf{L C 5 0}(\boldsymbol{\mu g} / \mathbf{m L})$ & $\mathbf{L C 1 0 0}(\boldsymbol{\mu g} / \mathbf{m L})$ \\
\hline LME & 41.94 & 86.02 & 160 \\
RME & 50.66 & 63.78 & 100 \\
SME & 50.53 & 86.89 & 175 \\
\hline
\end{tabular}

\subsubsection{Effects on apode frog tadpoles}

Seven concentrations ranging from $50.66 \mu \mathrm{g} / \mathrm{mL}$ to $300 \mu \mathrm{g} / \mathrm{mL}$ in geometric progression having ratios of 1.16 (LME), 1.12 (RME) and 1.34 (SME), were tested on 7 lots of 5 frog tadpoles. The 3 methanolic extracts were also toxic on frog tadpoles. A dose-dependent ( $p$-value < 0.05) increase in the effects was registered (Figure 3).
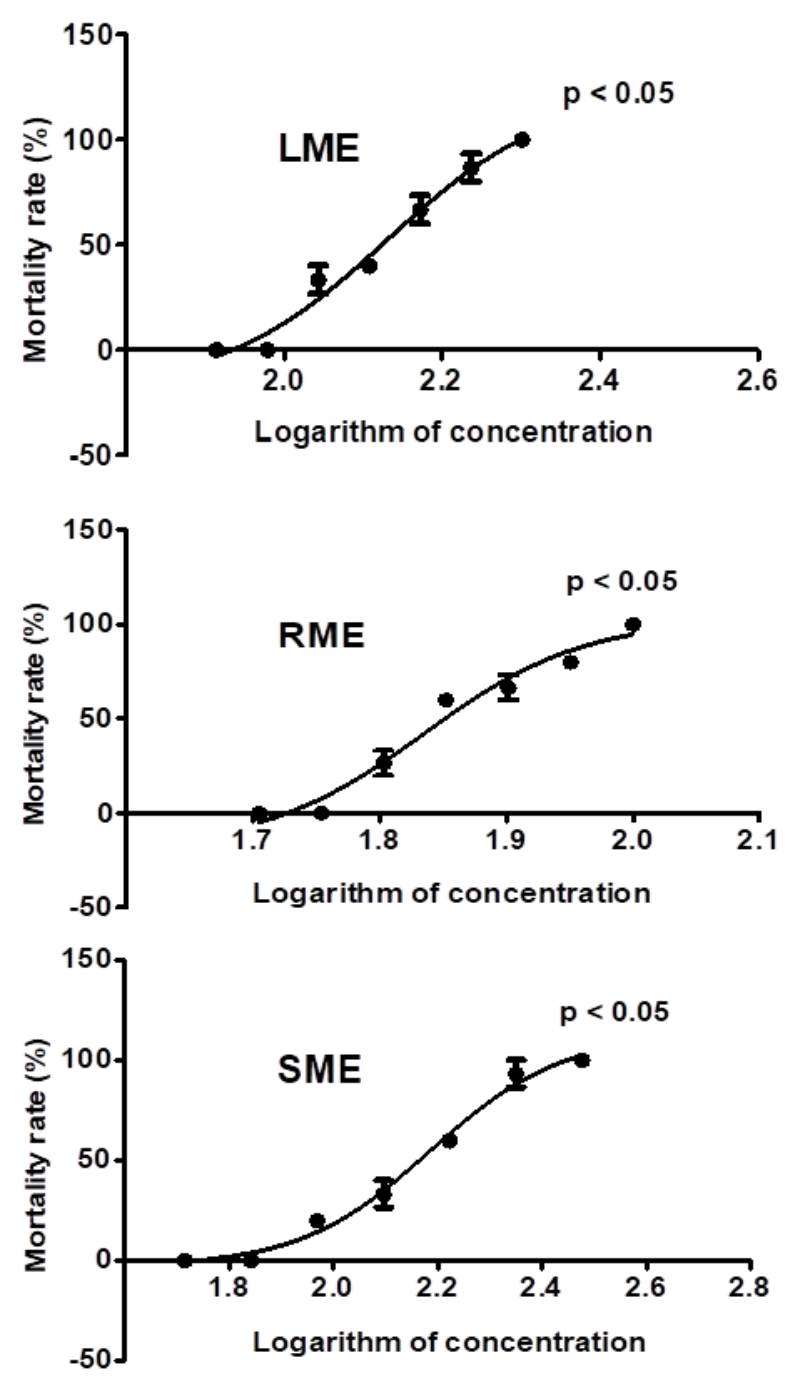

Figure 3 Concentration-effect curves of LME, RME and SME on frog tadpoles

$\mathrm{LC}_{0}$ varied from $50.66 \mu \mathrm{g} / \mathrm{mL}$ (RME) to $82.08 \mu \mathrm{g} / \mathrm{mL}$ (LME), LC $\mathrm{L}_{50}$ from $68.43 \mu \mathrm{g} / \mathrm{mL}$ (RME) to $153.4 \mu \mathrm{g} / \mathrm{mL}$ (SME) and $\mathrm{LC}_{100}$ from $100 \mu \mathrm{g} / \mathrm{mL}$ (RME) to $300 \mu \mathrm{g} / \mathrm{mL}$ for (SME) (Table 5). 
Table 5 Lethal concentrations (LC) of methanolic extracts on frog tadpoles

\begin{tabular}{llll}
\hline Extracts & LC0 $(\boldsymbol{\mu g} / \mathbf{m L})$ & LC50 & LD100 \\
\hline LME & 82.08 & 135 & 200 \\
RME & 50.66 & 68.43 & 100 \\
SME & 51.81 & 153.4 & 300 \\
\hline thal Concentration $0 \% ;$ LC $_{50}$ : Lethal Concentration 50\%; LC $_{100}$ : Lethal Concentration
\end{tabular}

\subsubsection{Effects on mosquito larvae}

All tested extracts showed no effect on Culex quinquefasciatus larvae after 24 h: neither death nor morbidity of larvae was registered.

\subsection{Effects of methanolic extracts on plant seed germination}

At $1 \mathrm{mg} / \mathrm{mL}, 7$ out of the 13 seed plants (53.8\%) were susceptible to 1 or 3 of the methanolic extracts (Table 6).

Table 6 Inhibition rates (\%) of plant seed germination by the $A$. mahalao methanolic extracts $(1 \mathrm{mg} / \mathrm{mL})$

\begin{tabular}{lllll}
\hline Plant family & Species & LME & RME & SME \\
\hline Apiaceae & Daucus carotta & 20 & 40 & 86.67 \\
Asteraceae & Lactuca sativa & 0 & 50 & 100 \\
& Brassica chinensis & 0 & 50 & 50 \\
Brassicaceae & Brassica oleraceae & 0 & 0 & 13.34 \\
& Brassica sp & 0 & 0 & 0 \\
Cucurbitaceae & Raphanus sativus & 0 & 0 & 0 \\
Fabaceae & Cucumis sp & 90 & 100 & 100 \\
& Phaseolus vulgaris & 90 & 100 & 80 \\
Papilionaceae & Pisum sativum & 0 & 0 & 0 \\
Solanaceae & Glycine max & 0 & 0 & 0 \\
Poaceae & Lycopersicum esculentum & 20 & 0 & 0 \\
& Oryza sativa & 0 & 0 & 0 \\
\hline
\end{tabular}

The 3 extracts prevented selectively the seed germination of Daucus carotta, Cucumis sp. and Phaseolus vulgaris with inhibition percentages ranking from $20 \%$ to $100 \%$. However, they had no effect on the seed germination of Brassica sp, Raphanus sativus, Pisum sativum, Glycine max, Oryza sativa and Zea mays.

\section{Discussion}

The toxicity of $A$. mahalao extracts on warm and cold-blooded animals and plants was well established.

On mice, ip $\mathrm{LD}_{50}\left(24 \mathrm{~h}\right.$ ) values ranged from 69.18 (RME) to $123.03 \mathrm{mg} / \mathrm{kg}$ (SME) for the methanolic extracts. The $\mathrm{LD}_{50}$ of total alkaloids $(135.52 \mathrm{mg} / \mathrm{kg})$ and total saponosides $(131.22 \mathrm{mg} / \mathrm{kg})$ were higher that means less toxic. That could be explained by the fact that there was a partial synergetic action between them in the methanolic extracts.

All the A. mahalao extracts were less toxic than seed methanolic extracts from other Malagasy Albizia species whose $\mathrm{LD}_{50}$ values were less than $40 \mathrm{mg} / \mathrm{kg}$ [2] (table 7). 
Table $7 \mathrm{LD}_{50} 24 \mathrm{~h}$ on mice of methanolic extracts from different Malagasy Albizia species

\begin{tabular}{|c|c|c|c|}
\hline Albizia species & Methanolic extract of & $\mathbf{L D}_{50}$ & h \\
\hline A. greveana & Seeds & $1.13-2.30$ & \\
\hline A. tuleariensis & Seeds & $2.9-3.2$ & \\
\hline A. divaricata & Seeds & $5.33-7.39$ & \\
\hline A. viridis & Seeds & $6.72-8.04$ & \\
\hline A. masikororum & Seeds & $16.5-16.81$ & \\
\hline A. androyensis & Seeds & $35.27-41.55$ & \\
\hline A. aurisparsa & Seeds & $36.30-38.76$ & \\
\hline A. mahalao & Leaf, stem and root barks & 69.18-123.03 & \\
\hline
\end{tabular}

Compared with foreign Albizia species, the methanolic extracts of $A$. mahalao were also less toxic than seed extracts of A. adianthifolia $\left(\mathrm{LD}_{50}=6 \mathrm{mg} / \mathrm{kg}\right.$ ) [6] but more toxic than aqueous extract of $A$. zygia stem bark $(\mathrm{LD} 50=316.2 \mathrm{mg} / \mathrm{kg})$ [7].

The A. mahalao extracts could be used to fight against noxious animals like harmful rodents (mice and rats). It is important to note that Rhodocodon madagascariensis bulbs (Hyacinthaceae), with a LD 50 ( $24 \mathrm{~h}$ ) of $170 \mathrm{mg} / \mathrm{kg}$, have been a well-known rodenticide used in Madagascar [8, 9].

By po and sc routes, no visible signs and no mortality were observed on mice. This could be due either by enzymatic degradation of the bioactive principles in the digestive tract or their weak or non-absorption. The same results were observed on chicks by po route. However, by ip route, all the methanolic extracts showed no visible symptoms and no mortality on chicks which meant these animals were less affected by the tested extracts than mice.

On carp alvins, the $A$. mahalao methanolic extracts were by far less toxic $\left(63.78 \geq \mathrm{LC}_{50} \leq 86.89 \mu \mathrm{g} / \mathrm{mL}\right)$ than the seed methanolic extracts of several Malagasy Abizia species $\left(2.28 \geq \mathrm{LC}_{50} \leq 15 \mu \mathrm{g} / \mathrm{mL}\right.$ ) [2] (Table 8).

Table $8 \mathrm{LC}_{50} 24$ h on carp alvins of methanolic extracts from different Malagasy Albizia species

\begin{tabular}{lll}
\hline Albizia species & Methanolic extract of & LC50 $(\boldsymbol{\mu g} / \mathbf{m L})$ \\
\hline A. greveana & Seeds & 10 \\
A. tuleariensis & Seeds & 2.28 \\
A. divaricata & Seeds & 8.45 \\
A. androyensis & Seeds & 3.85 \\
A. aurisparsa & Seeds & 15 \\
A. mahalao & Leaf, stem and root barks & $63.78-86.89$ \\
\hline
\end{tabular}

On frog tadpoles, the $A$. mahalao methanolic extracts $(68.43 \geq \mathrm{LC} 50 \leq 153.4 \mu \mathrm{g} / \mathrm{mL})$ were less toxic than seed methanolic extracts from other Malagasy Albizia species tested ( $4.50 \geq \mathrm{LC}_{50} \leq 60 \mu \mathrm{g} / \mathrm{mL}$ [10] (Table 9).

Table $9 \mathrm{LC}_{50} 24 \mathrm{~h}$ on frog tadpole of methanolic extracts from different Malagasy Albizia species

\begin{tabular}{lll}
\hline Albizia species & Methanolic extract of & $\mathbf{L C}_{\mathbf{5 0}}(\boldsymbol{\mu g} \mathbf{m} \mathbf{m L})$ \\
\hline A. viridis & Seeds & 4.50 \\
A. masikororum & Seeds & 4.55 \\
A. bernieri & Seeds & 10.49 \\
A. aurisparsa & Seeds & 60 \\
A. mahalao & Leaf, stem and root $68.43-153.4$ \\
\hline
\end{tabular}

The high toxic effects on alvins and tadpoles were probably due to saponins which were found in large amount in tested A. mahalao organs especially in leaves. The toxicity of these compounds to cold blooded animals has been well-known. It accounts for the use of many plants containing saponins as poison fishing in several countries [11]. 
LME, SME and RME had no toxic effects on Culex quinquefasciatus larvae. However, methanolic extracts of leaf and seed of Albizia lebbeck were reported to have ovicidal and adulticidal effects against Culex quinquefasciatus, Aedes aegypti, and Anopheles stephensi [12] and Albizia amara was highly toxic to Anopheles stephensi [13]. It would be interesting to test the $A$. mahalao methanolic extracts on these mosquitoes responsible for the transmission of several dreaded diseases particularly in developing countries having poor socio-economic conditions.

Preliminary experiments on plant seeds were conducted in view of a double objective, to test the effects of the $A$. mahalao extracts on vegetables and to find out if they could be used in the control of undesirable plants. Like other Malagasy Albizia already studied [14, [10], LME, SME and RME prevented the germination of some plant seeds but the inhibitory effect varied according to both the extract and the target plants. Studies on the seeds and seedlings of weeds and invasive plants are ongoing in our laboratory.

At $1 \mathrm{mg}$ per disk, leaf extracts of $A$. mahalao inhibited the growth of various pathogenic bacteria such as Clostridium perfringens, Staphylococcus aureus, Enterobacter aerogenes, Listeria monocytogenes, Vibrio fisheri, Shigella flexneri and Salmonella enterica [5]. This dose was by far below the $\mathrm{LD}_{0}(69.32 \mathrm{mg} / \mathrm{kg})$ of LME which is a strong argument for the use of leaf extracts as efficient drug against these pathogenic bacteria. They might be employed as an alternative solution to chemical antibiotics. However, in-depth pharmacological studies were still needed to confirm this hypothesis.

Several chemical groups, particularly alkaloids and saponins, were found in LME, SME and RME [5]. These secondary metabolites were responsible for the toxicity of the Albizia mahalao. Their involvement in the toxicity of other Malagasy Albizia were already reported: Albodorine isolated from A. odorata was extremely toxic to mice with LD50 ( 24 h) of 9 $\mathrm{mg} / \mathrm{kg}$ [15], A. bernieri seeds contained alkaloids and saponins which were toxic to several pathogenic microorganisms such as Enterobacter cloacae, Streptococcus pyogenes, Yersinia enterocolitica, Candida albicans [3]. Further chemical and biological investigations would be necessary to determine the number and originality of the bioactive principles.

\section{Conclusion}

The results obtained in this study demonstrated the toxicity of $A$. mahalao on various organisms and showed their possible use to fight against noxious organisms. These new data increased knowledge of the Malagasy Albizia properties.

\section{Compliance with ethical standards}

\section{Acknowledgments}

The authors are grateful to the Institut Pasteur de Madagascar (IPM), for its helpful support to this work.

\section{Disclosure of conflict of interest}

The authors declare no conflict of interests.

\section{Statement of ethical approval}

All the tests on animals were approved and in line with the standard established by Ethics Committee of the IPM.

\section{References}

[1] Du Puy DJ, Labat JN, Rabevohitra R, Villiers J-F, Bosser J and Moat J (2002). The Leguminosae of Madagascar. Royal Botanic Gardens, Kew, Richmond, United Kingdom, 243-288.

[2] Randrianarivo HR, Razafindrakoto AR, Ratsimanohatra HC, Randriamampianina LJ, Rajemiarimoelisoa CF, Ramamonjisoa L, Ramanitrahasimbola D, Rakoto DAD and Jeannoda VL (2014). Toxic effects of seed methanolic extracts of endemic Albizia Species (Fabaceae) from Madagascar on animals. Journal of Life Sciences, 8(8), 676689.

[3] Randriamampianina LJ, Razafintsalama VE, Rakoto DAD, Randrianarivo HR and Jeannoda VL (2017). Antimicrobial activity of seed extracts from Albizia beriberi E. Fourn. (Fabaceae). Journal of Pharmacy and Biological Sciences, 12 (3), 72-79. 
[4] Razafindrakoto, AR, Randriamampianina, LJ, Razafintsalama VE, Randrianarivo, HR, Rakoto, DAD and Jeannoda, VL (2018). Antimicrobial activity of the extracts of Albizia masikororum R. Vig., a Fabaceae from Madagascar. African Journal of Microbiology Research, 12(20), 464-469.

[5] Razanatseheno AJ, Randriamampianina LJ, Randrianarivo HR, Rakoto DAD and Jeannoda VL (2019). Antibacterial potential of the Albizia mahalao Capuron extracts, a Fabaceae from Madagascar. Novel Research in Microbiology Journal, 3(6), 502-510.

[6] Neuwinger HD (1996). African Ethnobotany. Poisons and Drugs: Chemistry, pharmacology, toxicology. Germany: Chapman and Hall, 941.

[7] Okpo SO, Igwealor CO and Eze G (2016). Sub-acute toxicity study on the aqueous extract of Albizia zygia stem bark. Journal of Pharmacy and Bioresources, 13(1), 32-41.

[8] Boiteau P (1986). Médecine Traditionnelle et Pharmacopée. Précis de matière médicale malgache. Agence de coopération culturelle et technique, ACCT, Paris.

[9] Rakotobe L (2009). Etudes chimiques et toxicologiques de deux plantes toxiques: Dioscorea antaly Jum. et Perr. (Dioscoreaceae) et Rhodocodon madagascariensis Baker (Hyacinthaceae) Thèse de Doctorat en Sciences de la vie, spécialité Biochimie, Université d'Antananarivo et Muséum d'Histoire Naturelle.

[10] Randrianarivo HR, Ratsimanohatra HC, Razafndrakoto AR, Rajemiarimoelisoa CF, Randriamampianina LJ, Ramamonjisoa L, Rakoto DAD and Jeannoda VL (2014). Phytotoxic property of seed methanolic extracts from Albizia (Fabaceae) endemic species of Madagascar. Journal of Plant Sciences, 2(6), 256-265.

[11] Eeckhaut I, Caulier G, Brasseur L, Flammang P, Gerbaux P and Parmentier E (2015). Effects of holothuroid ichtyotoxic saponins on the Gills of free-living fishes and symbiotic pearlfishes. Biological Bulletin, 228, 253-265.

[12] Govindarajan M and Rajeswary M (2015). Ovicidal and adulticidal potential of leaf and seed extract of Albizia lebbeck (L.) Benth. (Family: Fabaceae) against Culex quinquefasciatus, Aedes aegypti, and Anopheles stephensi (Diptera: Culicidae). Parasitology Research, 114(5), 1949-1961.

[13] Vinayagam A, Senthilkumar N and Umamaheswari A (2008). Larvicidal Activity of Some Medicinal Plant Extracts against Malaria Vector Anopheles stephensi. Research Journal of Parasitology, 3, 50-58.

[14] Rakoto DAD, Randrianarivo R, El-Yachouroutui M, Arisoa AA, Raharisoa N, Rakotondrasoa N, Raoniharisoa P and Jeannoda V (2012). Effects of Extracts from Albizia (Fabaceae) Endemic Species of Madagascar on Vegetable Seedling Development. J. Chem. Chem. Eng, 6, 313-322.

[15] Rajemiarimoelisoa CF, Rakoto DAD, Randrianarivo HR and Jeannoda VL (2015b), Purification and Toxicity Study of a Saponin from Seeds of Albizia odorata, a Fabaceae from Madagascar. Journal of Plant Sciences, 3(5), $264-271$.

\section{How to cite this article}

Razanatseheno AJ, Randriamampianina LJ, Randrianarivo HR, Rakoto DAD and Jeannoda VL (2020). Evaluation of the Toxic Effects of Albizia mahalao Capuron Extracts, a Fabaceae from Madagascar, on Different Organisms. GSC Biological and Pharmaceutical Sciences, 11(2), 287-296. 